Journal of Qualitative Criminal Justice \& Criminology

\title{
Legalizing Recreational Marijuana: Comparing Ballot Outcomes in Four States
}

Kenneth Leon ${ }^{1}$, Ronald Weitzer ${ }^{2}$

${ }^{1}$ American University, ${ }^{2}$ George Washington University

Published on: Oct 01, 2014

Updated on: Aug 17, 2020

License: Creative Commons Attribution 4.0 International License (CC-BY 4.0). 


\section{ABSTRACT}

Medical marijuana is now available in 23 states, and its growing acceptance has paved the way for the legalization of recreational marijuana. This article examines four recent campaigns to legalize recreational marijuana - two failures and two successes. Using data from newspaper sources, interviews with key players, and other sources, we examine the factors that influence whether a ballot initiative succeeds or fails. We identify similarities and differences between the four measures, the social forces shaping the debate, their claims and counterclaims, and a set of factors that appear to increase the odds that a recreational marijuana ballot measure will be successful.

\section{Introduction}

The U.S. Government criminalizes cultivation, distribution, and possession of marijuana and labels it a Schedule I drug (i.e., no medical value and a high potential for abuse). Twenty-three states and the District of Columbia, however, now permit access to medical marijuana, and ballot measures to legalize recreational marijuana have gained some traction as well. The measures failed in Alaska (2000), Nevada (2006), California (2010), and Oregon (2012), but succeeded in Colorado and Washington in 2012.

The national context is important. Over half the population (52\%) have used marijuana according to one recent poll (CNN, 2014), and a growing number of Americans support legalization for recreational use. Public support for this rose from $12 \%$ in 1969 to $25 \%$ in 1980 to $31 \%$ in 2000 (Gallup, 2014), and has now passed the halfway mark: hovering between 55 and 58\% (CNN, 2014; Gallup, 2014). Whereas 70\% considered smoking marijuana "morally wrong" in 1987, only half as many (35\%) took this view in 2014 (CNN, 2014). The growing tolerance regarding recreational marijuana is partly a byproduct of the medical marijuana movement, with the latter paving a path for the decriminalization of recreational possession. Almost half the states now have practical experience with regulation of a substance that may be transferred from the medical to recreational sphere rather than embarking on an enterprise completely de novo. Earlier attempts to legalize marijuana possession-Alaska in 2000 and Nevada in 2006-arguably failed in part because there was not, at that time, a critical mass of medical marijuana states with a significant record of regulating the drug to serve as a precedent for recreational legalization. 1

This article examines the four most recent campaigns to legalize recreational marijuana in California, Colorado, Oregon, Washington. We identify similarities and differences in the provisions of the ballot measures, key proponents and opponents in each state, and the arguments they made in defense of their position. Because our analysis compares four cases, we cannot provide either an in-depth examination of any one case or a comprehensive account (in one article) of all the factors that 
influence the success or failure of such ballot initiatives. But our research does allow for the identification of major similarities and differences among the four cases and (b) some tentative explanations for ballot failure in California and Oregon and success in Colorado and Washington, explanations that can be tested in future research on other states with recreational marijuana ballot initiatives.

\section{Background}

Prohibitory drug laws have been liberalized in the past. Scheerer (1978) compared the reform of drug laws in Germany and the Netherlands in the 1970s, with Germany increasing sanctions against cannabis possession and distribution, while the Netherlands relaxed penalties for possession and inaugurated a limited kind of regulation. Both reforms were top-down legislative decisions, not driven by popular pressure. In fact, Scheerer argued, both the German and Dutch populations were, at the time, "adamantly punitive" toward drugs. But in the Dutch case, legislators took the initiative in advocating a more tolerant approach, whereas their German counterparts took the opposite position. Scheerer assumed that elite opinion largely determines public policy in the area of vice:

"Decriminalization normally occurs in spite of a punitive and repressive public, and not because it is welcomed by a community of liberal eggheads" (Scheerer, 1978, p. 590).

Reform was also top-down in the United States in the 1970s. At the national level, the Comprehensive Drug Abuse Act of 1970 eliminated mandatory-minimum penalties, reduced maximum sentences, eliminated a provision preventing convicted offenders from being eligible for suspended sentences or probation, and provided treatment for first-time offenders arrested for drug possession (Peterson, 1985). A key reason for this reform was the perception among members of Congress that young middle- and upper-class white drug users were victims of iconic drug traffickers (Peterson, 1985). Between 1973 and 1978 eleven state legislatures reduced punishment for possession of small amounts of marijuana (penalties consisted of a small fine). The eleven states were diverse and included all regions of the country. DiChiara and Galliher (1994) argued that a window of opportunity opened in the 1970s as a result of increasing arrests of middle- and upper-class youths coupled with the interests of law enforcement agencies, seeking more efficient use of limited resources. Like Peterson (1985), DiChiara and Galliher found that politicians are more likely to revisit the rules when high-status white youth become subject to punishment for victimless crimes. Decriminalization is a way of resolving a situation of "moral dissonance," where violators are seen as having high social status but low moral status (as offenders) (Lempert, 1974, p. 6). The 1970s experiment with decriminalization ended in the following decade: States that had previously decreased penalties for marijuana possession increased sanctions during the 1980s in the context of the Reagan administration's robust drug war.

More recent examples of top-down reform are Portugal's decriminalization of all illegal drugs in 2001 and Uruguay's legalization of cannabis in 2013. Both resulted from legislative action, following 
recommendations of a 1998 government-appointed commission in Portugal and a presidential proposal in Uruguay in 2013.

Despite these cases of state-driven reform and Scheerer's (1978) assumption that the public is not a major player in the reform of vice laws, recent history shows that top-down liberalization is not the only trajectory. Recent marijuana law reform has resulted from legislative action in some states, but was driven by popular ballot initiatives elsewhere; 12 of the 23 state medical marijuana laws resulted from ballot initiatives rather than legislative action.

The trend toward liberalization has not been linear. In 2012, for example, Arkansas voters rejected a medical marijuana measure and Oregon voters rejected a recreational marijuana initiative. Federal government intervention remains a possibility in states where marijuana possession is now legal, especially if a more conservative administration takes office after the 2016 national election. In the sphere of victimless crime, legal reforms often take the form of what Dombrink and Hillyard (2007) call problematic normalization, where initial progress toward normativity is contested or diluted or stymied altogether. This dynamic has been evident in conflicts over samesex marriage, doctor-assisted suicide, abortion, and prostitution (Dombrink \& Hillyard, 2007; Sharp, 2005; Weitzer, 2012). Regarding medical marijuana, problematic normalization in the form of post-enactment conflicts and implementation problems have occurred in several states, including disagreements over (a) commercialization: business involvement in medical marijuana; (b) health and public safety: perceived and actual risks; (c) proliferation: growing usage or the surge in dispensaries in some areas; and (d) eligibility issues: consumers who enter the system without genuine medical needs (Geluardi, 2010; Regan, 2011). Similar challenges are likely in the implementation of recreational marijuana systems (e.g., Fisher, 2014). Moreover, the medical and recreational sectors may have conflicting interests. Medical marijuana forces have tried to block some recreational initiatives, or specific aspects of them, because they compete economically with the medical sector. And the stakes are high: one analyst estimated the value of the medical marijuana industry in California alone at \$14 billion in 2009 (Geluardi, 2010).

This paper examines four recent cases of attempted legalization. Table 1 lists each ballot initiative, its outcome, previous decriminalization (i.e., legislative reduction of penalties), and the date medical marijuana was approved.

Table 1. Ballot initiatives in four states

\begin{tabular}{|l|l|l|l|l|}
\hline State & Year & Initiative & Outcome & $\begin{array}{l}\text { Medical } \\
\text { marijuana }\end{array}$ \\
& & & approved & Previous \\
decriminalizatio & \\
\end{tabular}




\begin{tabular}{|l|l|l|l|l|l|}
\hline California & 2010 & Proposition 19 & NO (53.5\%) & 1996 & $1975,2000,2010$ \\
\hline Oregon & 2012 & Measure 80 & NO (53.4\%) & 1998 & 1972,1995 \\
\hline Colorado & 2012 & Amendment 64 & YES (55.3\%) & 2000 & 1975 \\
\hline Washington & 2012 & Initiative 502 & YES (55.7\%) & 1998 & 2003 \\
\hline
\end{tabular}

Note: Previous decriminalization here refers to de jure reduction in criminal penalties or substitution of civil penalties, not removal of all penalties.

\section{Predictors of vice legalization}

Campaigns to decriminalize vice, such as prostitution, gambling, drugs, raise issues that are less salient in debates over more mundane issues. Vice-related ballot measures are highly susceptible to emotional appeals (e.g., addictive gambling, victimization of women), moral panic (e.g., impact on youths, proliferation of the vice, organized crime), and social justice and civil rights claims (e.g., samesex marriage) (Dombrink \& Hillyard, 2007; Sharp, 2005; Skolnick, 1988).

Scholars have identified a set of factors that enhance the odds that a particular vice will be decriminalized (Lenton, 2004; Skolnick, 1988; Weitzer, 2012), and we consider these factors relevant to our analysis of marijuana legalization. These analysts argue that the greater the number of such factors in any given case, the higher the chances of decriminalization or legalization:

1. Significant numbers of people engage in the vice, and they have conventional lifestyles; the vice is not concentrated in the lower-class or in a fringe subculture;

2. There is evidence that legalization will produce less harm than criminalization; e.g., the vice does not create dependency or interfere with one's ability to fulfill obligations and does not endanger public health more generally;

3. Production and distribution of the vice can be controlled by the authorities;

4. There is support for decriminalization from law enforcement, leading politicians, and/or business elites;

5. Young people can be shielded from the vice; involvement of minors will remain prohibited;

6. Adults who wish to avoid the vice can be shielded from it (e.g., restrictions on public use, advertising marijuana products);

7. The vice can be confined to the private sphere;

8. Decriminalization can produce revenue for the government;

9. Business owners can be vetted to eliminate those with previous felony convictions or ties to organized crime; 
10. The regulatory regime should be subject to regular review and modification if necessary; any oversight body should be independent of the purveyors of the vice.

Some of these preconditions are met across our four cases; we know, for example, that a significant number of Americans have used marijuana and that most of them have conventional lifestyles, crossing virtually all demographics. All four ballot measures prohibit minors from accessing legal marijuana, and all limit use to the private sphere. $\stackrel{2}{ }$ Beyond this, our analysis will determine, to the extent that our data permit, whether and how some of the other preconditions were addressed in the four ballot measures and the regulatory regimes stipulated in each measure.

However, the success of a marijuana ballot initiative depends on other variables as well-including the status of leading advocates and opponents, the nature of media coverage and editorializing, timing (national or midterm election; youth turnout), and whether the federal government was intervening or threatening to intervene if the measure passed. $\underline{3}$

We hypothesize that if a ballot initiative and its corresponding campaign outspend the interest group(s) that opposed it, it should be a substantive predictor of ballot initiative success. Conversely, should the opposition outspend the pro-campaign, the initiative would be significantly more likely to be defeated at the polls. Funding is a variable of interest due to the correlation between fundraising and successful election outcomes; laws tend to pass and candidates elected when they have more funding than their opponents.

Political climate is another variable of interest. First, is there an observable difference between ballot initiatives proposed during a national election year (2012) versus a year of midterm elections (2010)? Second, is there support, opposition, or silence from federal authorities (e.g., Justice Department, Office of National Drug Control Policy)? We expect that opposition from the federal government will impede the success of a ballot initiative. Third, what is the stance of elected state or prominent local officials and candidates (governor, mayors) with regard to the ballot initiative? We hypothesize that if the latter publicly endorse a recreational marijuana ballot initiative, it will be associated with higher support among the electorate and therefore more likely to pass at the polls.

The media are an important factor. Newspapers can influence public perceptions of proposed marijuana reforms through editorials and through the content of news reporting. We hypothesize that endorsement of a ballot initiative from a state's major newspapers increases the odds of its passage.

Establishing all necessary and sufficient conditions of ballot success is a lofty goal for a qualitative examination of four cases. However, our analysis does allow for the identification of certain key variables and consideration of some tentative explanations for the success and failure of ballot measures that can be tested in future research on other cases. 


\section{Methods}

The cases examined were California, Colorado, Oregon, and Washington. California's ballot initiative took place in 2010, the other three in 2012 (see Table 1). Data were derived from three main sources. First, we content-analyzed articles in two major newspapers in each of the states: the Los Angeles Times $(\mathrm{n}=50)$ and San Francisco Chronicle (30) in California; Denver Post (35) and The Gazette (20) in Colorado; The Oregonian (29) and Statesmen Journal (8) in Oregon; and Seattle Times (90) and Tacoma News Tribune (17) in Washington. All articles that were available via the source website were included from the beginning of coverage of the ballot measure until the voting date - for a total of 279 articles. For each major state newspaper, we selected all articles that included the names of the ballot initiative (e.g. Initiative 502, I-502; Proposition 19, Prop. 19), and articles that included the keywords "marijuana" and "legalization." We also examined editorials regarding each measure in secondary newspapers in each state.

Using a grounded theory approach, we coded for items that appeared to have influenced whether a measure passed or failed. Primary coding categories included: prominent individuals and organizations that took a position regarding the ballot initiative; sources of campaign funding; general framing; specific arguments in favor and against the initiative; role of the state's medical marijuana sector; and key areas of concern as expressed or reported in leading newspapers. The frequencies of specific themes and arguments in newspaper articles and editorials were documented to establish which factors seemed to be the most relevant in each state. All articles were open-coded and recoded after specific themes and variables of interest became apparent. Themes and the way in which ballot initiatives were framed were drawn largely from editorials and the substantive arguments present in state news reporting. For example, if racially disparate criminal justice outcomes were referenced more than the expected tax revenue from legalizing cannabis, then the frame of social justice would be stronger than the frame of fiscal benefits. On the opposition side, the dominant frames might vary from state to state: e.g., fear of increased use among minors; predicting federal intervention to block implementation; concern that passage would only exacerbate existing problems associated with the medical marijuana system (allegedly "out of control" in some states), etc.

Second, newspaper data were cross-checked and expanded upon via interviews with two activists or experts in each state, most of whom played an active role in either formulating the initiative or contributing to the debate (see Appendix A). Ethics approval for the human subjects aspect of the study was granted by the university's IRB, and interviewees gave informed consent to be interviewed and identified in the study. Third and last, we conducted a content analysis for the key themes and messages in a small selection of television advertisements, recorded debates, and town hall meetings involving the ballot measures. 


\section{Findings}

The four ballot measures were similar in some respects: Possession is restricted to persons over age 21; public use is outlawed; tax revenue can be produced (if marijuana is purchased at a store); drugged driving is prohibited; and employers may prohibit use at the workplace and/or off-work via drug testing. The prohibition on youth involvement, public use, and drugged driving, and the provision for tax revenue satisfy four of the ten preconditions for vice-legalization previously listed. Our four cases differ, however, in other significant respects.

\section{California}

2010 was not California's first attempt at marijuana legalization. A 1972 ballot initiative (also called Proposition 19) would have decriminalized possession, cultivation, processing, and transporting marijuana for persons age 18 and older, and it would have prohibited persons under the influence from "engaging in conduct that endangers others." No other regulations were stipulated. The measure mustered only $33.5 \%$ support among voters.

California's second Proposition 19, in 2010, won more approval than its 1972 predecessor but was rejected by $53.5 \%$ of voters, despite the $\$ 4.5$ million spent in support of it (compared to the $\$ 420,000$ spent by opponents). The provisions included:

- Adults 21 and older may possess, cultivate, or transport marijuana for personal use;

- Possession and cultivation must be solely for personal consumption, not for sale to others; individuals may cultivate on private property in an area up to 25 square feet;

- Local governments may authorize, license, regulate, and tax the retail sale of marijuana and the location of businesses;

- Possession is prohibited on school grounds, as is adult use with minors present and providing marijuana to anyone under 21;

- Consumption is permitted only in a residence or other private space, except that marijuana may be consumed in licensed establishments if allowed by local laws;

- Current prohibitions against driving while impaired are retained;

- The measure does not specifically permit employers to drug test employees, but the measure states that it does not affect existing laws prohibiting use of drugs in the workplace.

Major backers included the ACLU, Marijuana Policy Project, Drug Policy Alliance, United Food and Commercial Workers Union, National Black Police Association, NAACP's California branch, Law Enforcement Against Prohibition (LEAP), and progressive financier George Soros. Arguments in favor of the measure included anticipated tax revenue; the potential for job growth; reducing racial disparities in drug arrests; and the argument that the state's medical marijuana system was allowing many ineligible users to obtain marijuana, thus necessitating a broader legalization remedy. 
Opposing forces included the Chamber of Commerce, the state's four leading newspapers, and various organizations (e.g., Police Chief's Association, Public Safety First). Fear of increased use among youth was particularly strong in California, as well as the concern that roads, workplaces, and communities would be less safe. The Drug Free American Foundation (2010) released television ads warning voters that use by minors would skyrocket and that intoxicated drivers would create dangers on the roadways. One of the most prominent arguments against the initiative was that it would not generate tax revenue because it allowed for personal cultivation and contained only a local option of creating taxable retail outlets. Opponents also warned that thousands of acres of farmland would be allocated toward marijuana cultivation (Drug Free America Foundation, 2010). Additionally, a major alleged defect of the proposition was the provision that allowed counties and municipalities to devise their own regulations or ban retail sales outright, which they argued would create a hodgepodge of policies throughout the state.

Opposition was voiced across the state's political spectrum: by Gov. Arnold Schwarzenegger (R), both 2010 candidates for governor and for state attorney general, California's two U.S. Senators (Barbara Boxer [D], Dianne Feinstein[D]), and House Speaker Nancy Pelosi (D). Perhaps even more importantly, national officials took a strong stand against the measure. The current and five former national drug czars and the U.S. Attorney General publicly opposed Proposition 19, which may have fueled public concern about possible legal battles if the measure passed. A few weeks before the election, Attorney General Eric Holder announced that federal authorities would "vigorously enforce" federal marijuana laws in California regardless of whether Proposition 19 passed; he stated that the Justice Department "strongly opposes" the measure and that passage would be to "the detriment of our citizens" (quoted in Hoeffel, 2010b). As one of our interviewees, the director of NORML's California branch, stated, "Towards the end of the Prop. 19 campaign, the Attorney General and the administration came out rather strongly against the initiative and I think that may have given people second thoughts as to whether the whole thing was feasible" (Gieringer interview). Nate Bradley of LEAP agreed that when the Attorney General "said they were going to vigorously enforce the law, that took even more momentum away" (Bradley interview). Such federal opposition in 2010 was not replicated in the three states with ballot initiatives in 2012, and we consider this a significant variable contributing to the successful outcomes in Colorado and Washington (cf. Kamin, 2012).

It is noteworthy that the organization representing the state's medical marijuana sector, the California Cannabis Association, opposed Proposition 19; they feared that the provision allowing local jurisdictions to ban dispensaries would lead to closure of existing medical marijuana stores in some areas. One of the strongest criticisms of the measure centered on the proliferation of medical marijuana stores in the state, and the corollary claim that the medical sector was "out of control," which recreational availability would only aggravate. The rapid spread of medical dispensaries was especially controversial in Los Angeles. Just a few months before the election, the Los Angeles city 
council ordered the closure, by June 7, 2010, of 439 medical marijuana dispensaries in the L.A. area, allowing another 130 to remain (Hoeffel, 2010a). Many of the stores had opened in violation of a moratorium on new dispensaries and had been the target of complaints from nearby residents (Hoeffel, 2010a). The surge in under-regulated medical marijuana stores-in Los Angeles and some other parts of the state-may have influenced some voters' decisions to vote against Proposition 19. A statewide poll found that $38 \%$ of California's registered voters opposed allowing marijuana dispensaries to operate in their city or town-39\% in Los Angeles and 30\% in the liberal San Francisco bay area (Field Research Corporation, 2013).

Other contentious issues included the ballot provision allowing local jurisdictions to decide how to regulate marijuana: "The local-option framing of it, where you'd have a different law in every city and county of California, sets up a chaotic system, which I think scared off a lot of people" (Gieringer interview). In addition, the "wording that limited the right of employers to do drug testing ... was enough to set off fire alarms at the Chamber of Commerce, and so the Chamber of Commerce and other business interests became galvanized in opposing the initiative" (Gieringer interview). (As noted, the measure did not mention drug testing but did allow employers to prohibit drug use at work.) An op-ed article in the Los Angeles Times by six former national drug czars cited a host of other anticipated problems: Usage would increase; tax revenues would be meager because users could grow their own supply and thus be free of taxes; and the number of intoxicated drivers on the roads would skyrocket, leading to more accidents and fatalities (Kerlikowske et al., 2010). A September 2010 editorial in the Los Angeles Times labeled the measure "an invitation to chaos":

It would permit each of California's 478 cities and 58 counties to create local regulations regarding the cultivation, possession, and distribution of marijuana ... The proposition would have merited more serious consideration had it created a statewide regulatory framework for local governments, residents, and businesses. But it still would have contained a fatal flaw: Californians cannot legalize marijuana. Regardless of how the vote goes on Nov. 2, under federal law marijuana will remain a Schedule I drug, whose use for any reason is proscribed by Congress. Sure, California could go it alone, but that would set up an inevitable conflict with the federal government that might not end well for the state. That experiment has been tried with medical marijuana, and the outcome has not inspired confidence. (Los Angeles Times, 2010)

These objections were echoed in the state's three other leading newspapers. The San Diego UnionTribune (2010) published an editorial entitled "No to Ganja Madness," again predicting that "chaos" would result from the patchwork of regulations among jurisdictions; that the current "explosion" of medical dispensaries in the state would skyrocket under recreational legalization; and that the measure would create a "collision course" with the federal government. Similar arguments were made by the San Jose Mercury News (2010) and the San Francisco Chronicle (2010), which called the medical 
marijuana system a "nightmare for many communities" that would only be magnified by Prop. 19 because of the lack of "state controls over distribution and product standards." The Chronicle also worried about the "stench" of 25 square-foot outdoor marijuana gardens in residential areas.

Even some of those who supported the principle of legalization considered Proposition 19 poorly framed. Television ads funded by Public Safety First and the No-on-19 campaign called the measure "a jumbled, legal nightmare."

A recent Huffington Post/YouGov (2014) poll reported that two-thirds of Americans favored allowing people to smoke marijuana in a private residence and a majority in a members-only marijuana club, but only a small minority thought that people should be allowed to smoke marijuana on a public sidewalk (15\%), park (18\%), or in a bar $(25 \%)$.

In sum, the major reasons for Proposition 19's failure included opposition of the state's leading newspapers representing the four largest cities, alleged flaws in the state's existing medical marijuana regime, and strong opposition from state politicians and federal officials.

\section{Oregon}

Two years later, Oregon's ballot measure was rejected by the same margin as California's: $53.4 \%$ voted against it. Measure 80 would have:

- Allowed adults to grow and possess any amount of marijuana;

- Permitted sales and cultivation, with regulations to be provided by a new Cannabis Commission;

- Mandated a drug education program for youth arrested for possession;

- Created a seven-member Cannabis Commission, five of whom would represent growers and processors; the commission would oversee zoning and licensing and would be mandated "to promote Oregon cannabis products in all legal national and international markets," in the words of the ballot measure;

- Required Oregon's attorney general to defend the new law and actively advocate for similar laws nationally and internationally.

The most popular arguments in favor of the measure were that it would regulate an existing illegal market, raise substantial public revenue, and increase public safety. Supporters estimated that a potential $\$ 140$ million would be gained in tax revenue, while $\$ 60$ million would be saved in reduced law enforcement costs (KATU News, 2011). Some advocates also packaged the measure as being consistent with the culture of the Pacific Northwest, a culture that combines progressive and libertarian values. Indeed, Oregon

was the first state to allow doctor-assisted suicide, to allow voting by mail, and to decriminalize marijuana in the 1970s (a violation punishable by a maximum $\$ 100$ fine). This legacy was depicted as a 
cultural context that was favorable to drug legalization.

The rationales inscribed in the ballot measure were unique in some respects. The Preamble to Measure 80 invokes George Washington, Thomas Jefferson, and the Book of Genesis to support legalization. It proclaims that "George Washington grew cannabis for more than 30 years" and that Thomas Jefferson invented a device to process hemp. Part of the Preamble offers a rather awkward and convoluted justification:

cannabis prohibition is a sumptuary law of a nature repugnant to our constitution's framers and which is so unreasonable and liberticidal as to ... unnecessarily proscribe consumption of a "herb bearing seed" given to humanity in Genesis 1:29, thereby violating their unqualified religious rights under Article 1, Section 3 and their Natural Rights under Article 1, Section 33 of the Oregon Constitution [and] violates the individual's right to privacy and numerous other Natural and Constitutional Rights.

Paul Stanford, the chief proponent of Measure 80, later reflected:

The Preamble talked about some historical and scientific facts about marijuana and cannabis, and The Oregonian's editorials and commentary painted that negatively as a manifesto for cannabis and belittled it, even though the facts cited therein were incontrovertible. The Preamble turned out to be a liability, politically, and was used against it. (Stanford interview)

The original draft of Measure 80 would have created an oversight commission whose members would be appointed by the governor. This was changed in the final draft to a grower-dominated commission ( 5 of its 7 members), which fueled concern that oversight would be hollow or biased toward the industry. The state's leading newspaper, The Oregonian (2012), called this "equivalent to putting Philip Morris in charge of state tobacco policy," and even the measure's top advocate considered this a blunder:

Several advocates in the cannabis community ... said that we shouldn't give the governor that much leeway [appointing commission members]. So we made that [change to grower-dominated] ... In retrospect, that was a mistake. We should not have had people in the industry compose five out of seven members of the commission. (Stanford interview)

The Oregonian (2012) branded the measure "comical" and "surreal" and stated, "Voters should reject this initiative and ask state and federal leaders for more coherent drug policies." This editorial compared Oregon's measure unfavorably to Colorado and Washington's because the latter impose limits on possession and on the number of retail outlets and give oversight responsibility to a government agency rather than a grower-dominated commission. 
The newspaper of the state capitol, Salem, focused on other dangers. It claimed that marijuana was both "addictive" and a "gateway drug" leading users to experiment with other illegal substances, and argued that passage would inevitably make marijuana more available to minors. In addition, persistent use "leads to a decline in brain functioning" (Statesman Journal, 2012). The main newspaper in liberal Eugene, Oregon, derided the measure's romanticized depiction of cannabis use: In addition to noting the measure's clash with federal marijuana law, The Register-Guard (2012) denounced it as an attempt to create a "cannabis culture" in Oregon:

Measure 80 is not an attempt to accommodate the reality of widespread and mostly harmless marijuana use. Instead, it aims to create a new reality, making Oregon into a state where the recreational use and commercial development of marijuana is not simply tolerated but celebrated. ... It is not just anti-prohibition-it's overtly pro-pot.

The latter is a reference to the provision requiring state authorities to advocate legalization in other states. The newspaper also belittled the "sponsor's evangelistic attitude" in invoking Genesis and the Founding Fathers.

Finally, in a public debate on the measure, District Attorney Josh Marquis used the novel argument (against the measure) that there was no need for it because possession was already sufficiently decriminalized: Measure 80 was a "solution searching for a problem" because, he claimed, possession of less than one ounce is currently treated leniently in Oregon (City Club, 2012).

The pro-legalization camp had a deficit of elite backing. Supporting the measure were the Oregon chapter of the National Association of Criminal Defense Lawyers, the medical marijuana sector, some local politicians, and the NAACP's regional branch. But strongly opposing the measure were the state's three largest newspapers, Gov. John Kitzhaber (D), the Sheriff's Association, and the District Attorney's Association.

The measure's radical provisions, dubious historical/religious/natural-law justifications, lack of elite sponsors, and opposition from the state's three largest newspapers were the main reasons for the measure's defeat. But even against these odds, it is noteworthy that fully $47 \%$ of voters supported the initiative, perhaps because proponents outspent opponents $\$ 531,000$ to $\$ 71,000$.

\section{Colorado}

Colorado's Amendment 64 passed by 55.3\%. Its provisions include:

- Possession of up to one ounce is allowed for persons 21 years of age and older;

- A resident can cultivate up to six plants in an enclosed, locked space;

- Both state residents and non-residents can purchase marijuana; 
- Oversight and licensing of cultivation facilities, product manufacturing sites, and retail stores by the Department of Revenue, which also regulates alcohol and tobacco;

- Local authorities will determine the location and number of marijuana stores in their jurisdictions; local officials may prohibit cultivation and manufacturing facilities as well as retail stores in their jurisdiction;

- Marijuana stores are subject to state and local sales taxes;

- A DUI/DWI provision may be established by the Governor and Department of Revenue (but was not mandated in the Amendment 64).

The organization Smart Colorado led the opposition campaign and raised $\$ 433,000$ to fight the measure (half of which came from the Florida group, Save Our Society From Drugs). Other vocal opponents included the Denver Chamber of Commerce, the Denver Post, Focus on the Family, Citizen Link, Visit Denver, Downtown Denver Partnership, Gov. John Hickenlooper (D), Denver Mayor Michael Hancock (D), the Colorado Education Association, law enforcement organizations, U.S. Attorney spokesman Jeff Dorschner, and former ONDCP official Kevin Sabet. Law enforcement groups either opposed or abstained from taking a position (e.g., opposition came from the Colorado Drug Investigator's Association, a trade group for drug enforcement officers). Given the wide variety of sectors represented by these actors, their reasons for opposing the amendment were multifaceted.

Arguments against the amendment included: (a) the standard claim that marijuana would become more available to youths; (b) an expected battle with the federal government over marijuana policy; (c) a concern that nonresidents would flock to Colorado for the purpose of "marijuana tourism"; and (d) a concern in the business community that legal cannabis would harm the state's reputation and make it harder to recruit new businesses to the state. A Denver Post (2012) editorial echoed some of these points while rejecting others. It began by declaring that possession should be legalized-at the national, not state, level. Rejecting the idea that legalization would put youth at risk, the editorial drew a parallel with the underage ban on alcohol purchases. What worried the Denver Post's writers was the anticipated clash with the federal government and the fear that Colorado would become a magnet for out-of-state buyers, growers, and distributors. The opposition argument in California that delegating regulatory decisions to local authorities would create an unworkable patchwork and that a single, statewide model was preferable was not a major opposition argument in Colorado, nor was California's claim that the medical marijuana sector was already out of control echoed in the Colorado debate.

The Chamber of Commerce's opposition was based on several concerns. While proponents favored the potential revenue that would result from taxing marijuana distributors, big business countered that becoming a marijuana-friendly state would damage the state's image and perhaps deter new investment. They also feared that passage would result in businesses having to modify their drug-free 
policies, perhaps allowing marijuana use by employees. The latter concern was unfounded: Under the regulations effective January 1, 2014, employers retain the right to fire workers who are intoxicated at work.

Economic justifications for Amendment 64 included the claim that passage would create at least 350 jobs and that substantial new tax revenue would be generated. Indeed, some businesses liked the possibility that Colorado might become a hub for marijuana tourism, generating demand for hotels, restaurants, rental cars, and other services.

The pro campaign outspent the opposition 4 to 1 : $\$ 3.5$ million vs. $\$ 707,000$. Fundraisers included the Campaign to Regulate Marijuana Like Alcohol (raising \$1.3 million) and the Marijuana Policy Project $(\$ 830,000)$. The two largest individual donors were Scott Banister, a San Francisco Internet entrepreneur, and Peter Lewis, chairman of Progressive Insurance Company. Other supporters include former Republican congressman Tom Tancredo, the Colorado branch of the NAACP, a coalition of more than 300 physicians, the United Food and Commercial Workers Union (Colorado's largest union), and the Colorado Center on Law and Policy. Having bipartisan support from a well-known rightwing politician, Rep. Tom Tancredo as well as the Colorado Democratic Party may have contributed to the measure's success (Tvert interview). More importantly, unlike in California, the medical marijuana community was largely supportive of the measure, evidenced by a petition drive in which more than 150 medical marijuana-related businesses allowed volunteers to collect signatures inside their stores. Colorado's medical sector supported Amendment 64 partly because the provisions of the new law gave preferential status and other benefits to existing medical marijuana businesses (indeed, as of January 2014, the only dispensaries where recreational users could obtain the drug were existing medical marijuana stores). The unified stance of the medical and recreational sectors differed from the other states.

\section{Washington}

Washington legalized recreational marijuana by the same margin as Colorado, with $55.7 \%$ voting for it. A poll of voters one day after the election found that support was strongest among Democrats, liberals, moderates, those with higher education, and families with $\$ 100,000+$ income; opposition came from older age groups, conservatives, Republicans, the highly religious, and the less educated (Associated Press, 2012). Initiative 502 provided for the following:

- Removes penalties for marijuana production, distribution, and possession for persons 21 and over, but does not allow personal cultivation;

- Designates the Washington State Liquor Control Board as the regulating authority;

- Taxes marijuana sales and earmarks marijuana-related revenues;

- Tightly regulates and licenses distribution, similar to the state control of alcohol; 
- Prohibits growing marijuana for recreational purposes in private residences and allows only medical marijuana patients to do so;

- Imposes an excise tax of $25 \%$ at each point of transfer between manufacturers, processors, and retailers;

- Prohibits marijuana stores near schools, daycare and youth centers, parks, and libraries;

- Outlaws public use or display;

- Allows employers to dismiss employees who test positive for THC;

- Establishes a blood-test limit for driving under the influence.

Key opponents included medical marijuana entrepreneurs, law enforcement officials, substance abuse staff, and Gov. Christine Gregoire (D), whose opposition was mainly based on concerns over federal government intervention if the measure passed. In addition, the two candidates for governor in the 2012 election both opposed I-502 due to their concerns about the impact on the medical marijuana sector. Representatives of the drug prevention and law enforcement sectors tended to focus on marijuana's harms, such as the risks to young people from early-onset use and the risk of mental health problems for adults who use the substance frequently.

As in California, the medical marijuana sector was a vocal opponent: "They showed up at most hearings and public meetings, and were loud and noisy ... They would get up and yell and interrupt meetings. People were influenced, so I think they were actually effective" (Martin interview). Sensible Washington, a medical marijuana association, offered several reasons for rejecting Initiative 502. They opposed the DUI provision, claiming that it had no scientific basis. And they argued that the measure was too restrictive, because it would effectively criminalize medical patients who needed the drug because their chronic use would make many of them test positive while driving a car. Sensible Washington also thought that individuals aged 16 to 20 should be eligible if their medical condition warranted consumption. So, in this case, the medical marijuana sector opposed the measure not because it would interfere with their own profits but instead because they considered the regulations too restrictive.

In a public debate with a proponent (Alison Holcomb of the ACLU), John Toker of Sensible Washington cited additional problems with I-502: First, he called it "pseudo-legalization" because it limits possession to only one ounce. Second, he advocated a system with fewer restrictions than the measure's elaborate set of regulations (Working People Unite, 2012). And third, Sensible Washington opposed the measure's prohibition on cultivation for personal use, which would harm medical marijuana users who may need a personal source of the drug (Elliot, 2012). Responding to this critique, proponents pointed out that I-502 prohibits personal growing for recreational use, but registered medical patients are permitted to continue growing limited amounts on their private property and can possess a 60-day supply of marijuana (New Approach Washington, 2012). 
Unlike the pro campaigns in the other three states, Washington's advocates highlighted a set of criminal justice problems to support legalization, an issue covered extensively by the Seattle Times and the Tacoma News Tribune. The argument centered on the harms of the law's overreach, enforcement costs, racialized law enforcement, and involvement of the criminal underworld in the marijuana trade - while failing to reduce usage. The campaign emphasized that over 241,000 state residents had been arrested for marijuana possession since 1986 and claimed that the cost of this enforcement was $\$ 306$ million, with blacks and Latinos arrested disproportionately (Marijuana Arrest Research Project, 2012). Social justice and harm-reduction framing was therefore quite prominent during this state's debate on the measure. One of our interviewees elaborated on this issue:

Efforts to prevent access to marijuana are largely ineffective, and these efforts come with great costs. Not only financial costs for the operation of the law enforcement and criminal justice system, but also with major social justice inequities in how the laws are actually implemented ... in terms of people of color being arrested far more than whites even though the epidemiological data make it clear that people of color use marijuana at a somewhat lower level. The campaign was also emphasizing that the tax revenues that this [new] legal market could generate could be put to good use in terms of public health and public safety. (Roffman interview)

Along with some other newspapers, such as The Olympian (Olympia, the state capitol) and The Spokesman-Review (Spokane), the measure won support from the Seattle Times (2012) editorial board:

For several years, recreational marijuana has effectively been decriminalized in Seattle, and there has been no upsurge in crime or road deaths from it. But even in Seattle, recreational marijuana is still supplied by criminals - by definition ... Initiative 502 aims to take the marijuana business out of the hands of gangs. That is what legalizing alcohol did in the 1930s.

The proponents of I-502 greatly outspent the opposition, spending \$6.2 million in comparison to their opponents' miniscule $\$ 16,000$ (Riggs, 2012). For the pro side, a substantial part of the funding came from George Soros and Peter Lewis of the Progressive Insurance Company.

The campaign gained legitimacy and credibility when a former US Attorney, John McKay, became a sponsor and published an op-ed article in the Seattle Times calling for legalization. The ranks of supporters included 16 state legislators, the former head of Seattle's FBI office Charles Mandigo, Seattle City Attorney Pete Holmes, and television evangelist Pat Robertson. Another influence on Washington voters may have been Rick Steves, a well-known travel writer who frequently appears on PBS channel travel shows. Reporter Jonathan Martin from the Seattle Times noted that Rick Steves is a "beloved figure in the Seattle area because he has a travel company that has been here a long time. He's a regular radio show. He's just a super folksy, easygoing guy. He was just a great face for the 
campaign" (Martin interview). Steves' support of I-502 added credence and popular appeal to the initiative.

Advocates for I-502 were effective in framing the initiative in terms of social justice and harmreduction benefits; legalization would reduce criminal justice inequities and reallocate law enforcement resources to important matters.

\section{Discussion}

Scheerer's (1978) state-centric, top-down model of drug legalization is clearly obsolete. The U.S. experience since 1996 with both medical and recreational marijuana measures demonstrates a citizendriven alternative to the legislative model. The decriminalization of possession in eleven states in the 1970s was done entirely within the halls of state legislatures, but of the 23 jurisdictions that now allow medical marijuana, 12 resulted from popular ballot initiatives.

With only four cases in the present study, it is difficult to say with certainty that any particular variable is more important than others in predicting whether a recreational ballot measure will succeed or fail. Moreover, the factors of interest cannot be subjected to quantitative analysis. Other limitations of this study include the lack of certain kinds of data (e.g., records of how campaign funds were used), the modest number of interviewees, and the fact that the latter discussed the ballot process in hindsight. But we have attempted to identify factors that appear to be important influences on ballot outcomes. Specific provisions within a measure can certainly shape the vote, especially if they attract (straight or sensationalized) media coverage and television and radio ads. But what also matters is how the measure is generally framed in the public square. California's measure was framed by opponents as a recipe for conflict with the federal government at a time of an escalating federal crackdown in the state and as lacking in statewide regulatory norms that would only exacerbate existing problems with the state's medical marijuana system. Oregon's measure was derided as "too radical," with no limits on possession or the number of cannabis stores and a regulatory commission that would have been dominated by the marijuana industry. In Colorado, more than the other states, the overarching framing was that marijuana was less harmful than and should be regulated like alcohol. And the dominant framing of Washington's measure was that legalization would help to promote social justice because it would remove marijuana from the criminal justice system and reduce racially disparate outcomes. In none of the three 2012 debates did the opposition emphasize the California argument that the medical marijuana system was out of control and that adding recreational marijuana to the mix would only make things worse.

In both Colorado and Washington, legalization was also framed as a public health and safety issue, less as a danger to public health and more as a way of advancing it. In Washington, legalization was presented as a way to further drug education, treatment, and controlled use. In Colorado, a key 
campaign message was that marijuana is objectively less harmful to health than alcohol, which was legal, thus seemingly justifying Amendment 64. Challenging the argument that usage and dependency would increase, proponents argued instead that legalization was consistent with a harm-minimization orientation that places education, health, and treatment, and not criminal justice, at the core of marijuana policy.

The role of the federal government is important. All four states had a preexisting medical marijuana sector, yet California's experience with federal action against medical marijuana establishments appears to have diluted support for Prop. 19. Federal intervention fueled concerns regarding how the government might respond to recreational legalization. Just two years later, the policy window opened as the Obama administration largely stayed silent during the November 2012 election, perhaps because this was a national election and the president wanted to avoid alienating supporters in the three states. .5 California was the only state that, at the time of the vote, experienced significant intervention from the Justice Department, which appears to have affected the amount of support for its legalization measure. In the area of drug reform, the role of the federal government is therefore an important factor in state-level legal change.

One question is whether funding for vice-legalization campaigns matters. It is perhaps no surprise that Oregon's radical measure was the least funded of the three 2012 ballot initiatives. Advocates raised $\$ 531,000$, which pales in comparison to the $\$ 6.2$ million in Washington and $\$ 3.5$ million in Colorado in support of the measures. As noted above, financial support for the Washington and Colorado measures far eclipsed the amounts raised by opponents, so it does appear that funding was a predictor in both states. But funding alone does not ensure success. California's failed measure received $\$ 4.5$ million from supporters, ten times more than the opposition's $\$ 420,000$. And despite the significant variations in funding, voter support for the two failed ballot initiatives was identical (California $46.5 \%$, Oregon's $46.6 \%$ ) as was support for the two successful measures (Colorado 55.3\%, Washington 55.7\%). In other words, while generous funding can help to sway voters on vice issues, other factors can outweigh campaign financing.

The age distribution of voters matters significantly. Two recent polls (Gallup 2014; CNN 2014) both reported that $67 \%$ of young adults endorse legalization of marijuana for recreational use. If a similar majority of youth in any given state support legalization, it can be argued that youth turnout may have a decisive effect on the outcome of marijuana ballot measures. The youth turnout figures in our four cases lend some support to this hypothesis. In California, the percentage of voters in the 18-29 age group declined by half between the 2008 general election (20\% of the vote) and 2010 midterm election (10\% of the vote) (Bacon, 2010). Had this age group turned out in the same numbers in 2010 as they did in 2008, it is possible that Proposition 19 would have won (Hoeffel, 2010c). In the other three states, youth turnout increased between 2008 and 2012: from 12 to $17 \%$ of voters in Oregon, 14 to $20 \%$ in 
Colorado, and 10 to 22\% in Washington (Atlas Project, 2013). The substantial rise in the youth vote may help to explain ballot success in Colorado and Washington. A Colorado poll taken in early October 2012 found that $56 \%$ of likely voters aged 18 -34 supported the ballot measure, compared to $48 \%$ of all likely voters (SurveyUSA, 2012), and a poll of registered voters in Washington conducted right before the election (in late October) found that fully 75\% of those aged 18-29 supported Washington's ballot initiative (KCTS, 2012).

The liberal political culture of the Pacific Northwest (e.g., only Oregon and Washington allow doctorassisted suicide) may have had a positive impact in Washington but could not overcome the perceived deficiencies of Oregon's measure. History shows that a state's political culture does not need to be progressive for the decriminalization of vice to occur; some conservative states decriminalized marijuana possession in the 1970s, whereas some vice-tolerant states like Nevada passed harsh laws (DiChiara \& Galliher, 1994; Galliher \& Cross, 1982). For this reason, we do not consider a state's historical political culture a robust predictor, although it may have some impact. Coupled with whatever influence the Northwest political culture may have had on the outcome in Oregon and Washington in 2012, Washington's initiative also had other pillars of support: substantial financial backing and support from a wide variety of actors. Having former federal law enforcement officials and the legal community publicly endorse the initiative gave tremendous gravitas to the campaign. However, the stance of candidates running for office or the incumbent governor were found to have limited impact on ballot outcomes, for there was wide variation on this measure among the cases.

Washington and Colorado's ballot measures satisfy many of the conditions that Lenton (2004), Skolnick (1998) and Weitzer (2012) outline as important factors for vice decriminalization, presented earlier in this article. However, as evidenced by the failures of California and Oregon's initiatives, even if many of these conditions are met, they do not ensure success. In addition, the dynamic process in which opposing forces and media outlets frame the ballot initiative generally and highlight specific benefits or problems with the measure is extremely important. It is difficult to assert that there is a best practices formula for drug policy reform, since there have been only four attempts to legalize recreational marijuana since the Obama Administration took office and one during the Bush era. Yet it does appear that meeting most, if not all, of the preconditions listed above can maximize the chances that a vice-related ballot measure will succeed in any given state. Our analysis also suggests that support from political leaders, law enforcement officials, the medical marijuana sector, public health community, and young voters are important-as is the central framing of the issue.

The policy implications of this research are significant. Legislators, advocates, public health officials, and law enforcement are using the experiences of Colorado and Washington to understand not only what policies are most sensible but also how to best engage the public and other interest groups in the discourse pertaining to vice legalization. Three jurisdictions have recreational legalization measures 
on the 2014 ballot: Alaska, Oregon, and the District of Columbia. Now that a widely-known precedent has been set (Colorado and Washington), it is possible that some of these measures will succeed, and recent polls show either slight or substantial majority support in each jurisdiction (Lopez, 2014), in addition to California (Field Research Corporation, 2013). Nationwide, support for legalization jumped a remarkable 10 percentage points in the year following the 2012 Colorado and Washington victories from 48\% in late November 2012 to 58\% in October 2013 (Gallup, 2014). Research on future ballot outcomes will help to confirm whether the factors identified in this study are corroborated as important in other contexts and thus have more general salience.

\section{Appendix}

\section{Appendix A. Interviewees}

\begin{tabular}{|c|c|c|c|}
\hline State ballot initiative & Name & Date interviewed & Professional affiliation \\
\hline \multirow[t]{2}{*}{ California Proposition 19} & Nate Bradley & May 3, 2013 & $\begin{array}{l}\text { Private Investigator. Former } \\
\text { law enforcement officer }\end{array}$ \\
\hline & Dale Gieringer & April 24, 2013 & $\begin{array}{l}\text { State Director National } \\
\text { Organization for the } \\
\text { Reform of Marijuana Laws }\end{array}$ \\
\hline \multirow[t]{2}{*}{ Colorado Amendment 64} & Mason Tvert & May 8, 2013 & $\begin{array}{l}\text { Director of } \\
\text { Communications- } \\
\text { Marijuana Policy Project }\end{array}$ \\
\hline & Brian Vicente & May 10, 2013 & $\begin{array}{l}\text { Co-author of Amendment } \\
64 \text {. Codirector of Campaign } \\
\text { to Regulate Marijuana Like } \\
\text { Alcohol }\end{array}$ \\
\hline \multirow[t]{2}{*}{ Oregon Measure 80} & Rep. Peter Buckley (D) & June 25, 2013 & $\begin{array}{l}\text { Co-Chair of the Joint } \\
\text { Committee on Ways \& } \\
\text { Means, Oregon House of } \\
\text { Representatives }\end{array}$ \\
\hline & Paul Stanford & May 8, 2013 & $\begin{array}{l}\text { Primary author of Measure } \\
80\end{array}$ \\
\hline Washington Initiative 502 & Jonathan Martin & May 3, 2013 & $\begin{array}{l}\text { Enterprise Reporter- } \\
\text { Seattle Times }\end{array}$ \\
\hline
\end{tabular}




\section{References}

Associated Press. (2012, November 7). Washington voters legalize recreational pot use. The SpokesmanReview.

Atlas Project. (2013). Marijuana ballot measures and youth turnout.

Bacon, P. (2010, November 3). Low turnout by young voters hurts democrats in midterm elections. Washington Post.

City Club of Portland. (2012). Measure 80 debate. YouTube.

CNN. (2014). Poll, January 3-5. CNN/ORC International poll. Atlanta, GA: CNN.

Denver Post. (2012, October 14). Amendment 64 is the wrong way to legalize marijuana. Editorial.

DiChiara, A. \& Galliher, J. (1994) Dissonance and contradictions in the origins of marihuana decriminalization. Law \& Society Review, 28, 41-78.

Dombrink, J. \& Hillyard, D. (2007). Sin no more. New York, NY: NYU Press.

Drug Free America Foundation. (2010). No to Prop 19. YouTube.

Elliot, S. (2012). Sensible Washington: Here's why we oppose I-502 “legalization." Toke of the Town.

Field Research Corporation. (2013). The field poll, no. 2442, February 5-17.

Fisher, M. (2014, July 27). A dividing line. Washington Post.

Galliher, J. \& Cross, J. (1982). Symbolic severity in the land of easy virtue: Nevada's high marihuana penalty. Social Problems, 29, 380-386.

Gallup Poll. (2014). Illegal drugs (1969-2013 polls). Retrieved from http://www.gallup.com/poll/ 1657/illegal-drugs.aspx

Geluardi, J. (2010). Cannabiz: The explosive rise of the medical marijuana industry. Sausalito, CA: PoliPoint Press.

Hoeffel, J. (2010a, May 5). L.A. Orders 439 Medical Marijuana Dispensaries to Close. Los Angeles Times. Hoeffel, J. (2010b, October 16). Holder Vows Fight Over Prop. 19. Los Angeles Times. 
Hoeffel, J. (2010c, November 3). Youth Vote Falters, Prop. 19 Falls Short. Los Angeles Times.

Huffington Post/YouGov. (2014). Poll, July 28-31.

Kamin, S. (2012). Medical marijuana in Colorado and the future of marijuana regulation in the United States. McGeorge Law Review, 43, 147-167.

KATU News. (2011, March 28). Push to sell marijuana in Oregon kicks off. KTCS 9 Washington Poll.

Kerlikowske, G., Walters, J., McCaffrey, B., Brown, L., Martinez, B., \& Bennett, W. (2010, August 25). Why California should just say no to prop. 19. Los Angeles Times.

Lempert, R. (1974). Toward a theory of decriminalization. University of Michigan Public Law Working Paper, No. 209.

Lenton, S. (2004). Pot, politics, and the press: Reflections on cannabis law reform in Western Australia. Drug and Alcohol Review, 23, 223-233.

Lopez, G. (2014, August 7). DC, 3 states, and a U.S. territory will vote on marijuana this year. Vox.com.

Los Angeles Times. (2010, September 24). Snuff out pot measure. Editorial.

Marijuana Arrest Research Project. (2013). 240,000 marijuana arrests: Costs, consequences, and racial disparities of possession arrests in Washington, 1986-2010.

New Approach Washington. (2012). Backgrounder: I-502 and medical marijuana. Yes on I-502-New approach Washington.

No on Prop 19. (2010). No on proposition 19 radio ad. YouTube.

Peterson, R. (1985). Discriminatory decision making at the legislative level: An analysis of the comprehensive drug abuse prevention and control act of 1970. Law and Human Behavior, 9, 243-269.

Regan, T. (2011). Joint ventures: Inside America's almost legal marijuana industry. Hoboken, NJ: Wiley.

Register-Guard. (2012, October 3). Marijuana legalization: No. Measure 80 overreaches, underregulates. Editorial.

Riggs, M. (2012, November 16). In Washington, marijuana proponents outspent opponents 400 to 1 . The New Republic.

San Diego Union-Tribune. (2010, October 18). No to ganja madness. Editorial.

San Francisco Chronicle. (2010, September 16). Proposition 19: Vote no. Editorial. 
San Jose Mercury News. (2010, October 13). No on proposition 19: Legalizing marijuana is inevitable, but this is the wrong way. Editorial.

Scheerer, S. (1978). The new Dutch and German drug laws: Social and political conditions for criminalization and decriminalization. Law \& Society Review, 12, 585-606.

Seattle Times. (2012, September 22). Approve initiative 502-It's time to legalize, regulate, and tax marijuana. Editorial.

Sharp, E. (2005). Morality politics in American cities. Lawrence, KS: University of Kansas Press.

Skolnick, J. (1988). The social transformation of vice. Law and Contemporary Problems, 51, 9-29.

State of Colorado. (2013). Office of the governor and department of revenue. Task Force Report on the Implementation of Amendment 64.

Statesman Journal. (2012, November 1). Marijuana legalization deserves a "No" vote. Editorial.

The Oregonian. (2012, September 22). Vote no on measure 80, Oregon's marijuana manifesto. Editorial.

SurveyUSA. (2012). Results of Survey 19856. October 9-10, poll of likely voters.

Weitzer, R. (2012). Legalizing prostitution: From illicit vice to lawful business. New York, NY: NYU Press.

Working People Unite. (2012). I-502 debate-marijuana legalization in Washington state.

\section{Contributors}

Kenneth Leon is a $\mathrm{PhD}$ student in the Department of Justice, Law, and Criminology at American University with a dual specialization in socio-legal studies and criminology. His primary research interests include drug policy, state power and control, and qualitative methods. He received an MA degree in criminology from George Washington University and a BS degree in criminology from Florida State University.

Ronald Weitzer is a professor of sociology at George Washington University. He has written extensively on police relations with ethnic minorities in the United States and other countries, the sex industry, and human trafficking. His most recent book is Legalizing Prostitution: From Illicit Vice to Lawful Business (NYU Press, 2012).

\section{Footnotes}

1. Medical marijuana had been approved in only five states prior to Alaska's vote on recreational marijuana in 2000, and eleven states had approved it by the time of Nevada's 2006 vote on recreational marijuana. $ヒ$ 
2. A recent Huffington Post/YouGov (2014) poll reported that two-thirds of Americans favored allowing people to smoke marijuana in a private residence and a majority in a members-only marijuana club, but only a small minority thought that people should be allowed to smoke marijuana on a public sidewalk (15\%), park (18\%), or in a bar $(25 \%)$.

3. A November 2012 Gallup poll and a March 2013 Pew Research poll reported that $64 \%$ and $60 \%$ of Americans, respectively, felt that the federal government should not intervene to enforce federal marijuana laws in states that currently allow marijuana possession. In May 2014, the U.S. House of Represented voted (219-189) for a measure that would prevent federal government interference in states that allow cultivation, sale, and possession of medical marijuana. It remains to be seen whether the Senate will follow suit and whether the president will sign the bill. Since 2003, six similar measures had failed to pass the House. $\subseteq$

4. It is also possible that legislation in mid-2010 took some of the steam out of the legalization campaign. A bill, signed by Gov. Schwarzenegger, downgraded the penalty for possession of up to one ounce of marijuana from a criminal misdemeanor to a civil infraction with a maximum $\$ 100$ fine.

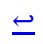

5. According to the text of Measure 80, Oregon's Attorney General would be required to defend the law against any federal challenges and prosecutions and also to "propose a federal and/or international act to remove impediments to this chapter, deliver the proposed act to each member of Congress and/or international organization, and urge adoption of the proposed federal and/or international act through all legal and appropriate means." 